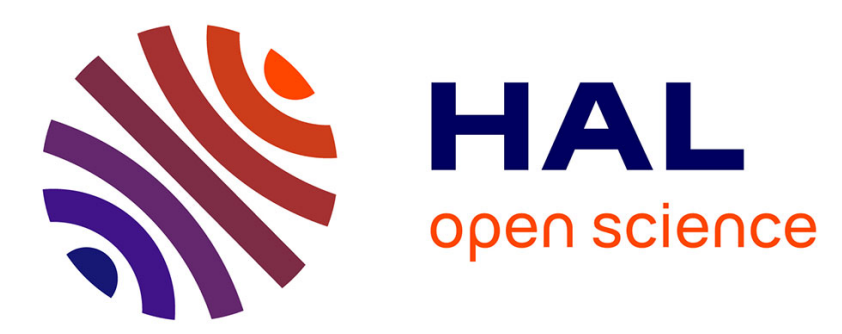

\title{
The Moon for a twopence: street telescopes in nineteenth-century Paris and the epistemology of popular stargazing
}

David Aubin

\section{- To cite this version:}

David Aubin. The Moon for a twopence: street telescopes in nineteenth-century Paris and the epistemology of popular stargazing. Early Popular Visual Culture, 2017, 15 (2), pp.125-151. 10.1080/17460654.2017.1318516. hal-03116348

\section{HAL Id: hal-03116348 \\ https://hal.sorbonne-universite.fr/hal-03116348}

Submitted on 20 Jan 2021

HAL is a multi-disciplinary open access archive for the deposit and dissemination of scientific research documents, whether they are published or not. The documents may come from teaching and research institutions in France or abroad, or from public or private research centers.
L'archive ouverte pluridisciplinaire HAL, est destinée au dépôt et à la diffusion de documents scientifiques de niveau recherche, publiés ou non, émanant des établissements d'enseignement et de recherche français ou étrangers, des laboratoires publics ou privés. 


\section{The Moon for a Twopence: \\ Street Telescopes in Nineteenth-Century Paris and the Epistemology of Popular Stargazing}

David Aubin*

1 March 2017

Abstract:

In this article, I explore the epistemology of popular stargazing as it emerged in the nineteenth century. I want to chart the way in which the spectacle of the sky, a powerful metaphor of the Enlightenment, became an object of mass consumption in nineteenth-century Paris. Turning astronomy into a spectacle for wide audiences, I want to argue, went hand-in-hand with the emergence renewed forms of popular observations. To this end, I focus on the telescopes that were set up in public places (boulevards, bridges, and squares). I am trying to reconstruct the workings of these small-scale enterprises, their appeal, as well as the various ways they were perceived by a socially diversified public. In brief, this paper is about how the crowd was convened to spectacle of the sky and about what was the meanings of this transformation in the popular gaze.

There is nothing natural about popular stargazing. In fact, we might go as far as saying that Western philosophy was constructed on the opposite premise. The popular and commonsensical concern with daily matters was incompatible with-if not antithetical to-the learned study of the sky. "Take the case of Thales," Plato famously wrote. "While

\footnotetext{
* Institut de mathématiques de Jussieu-Paris rive gauche (CNRS, Sorbonne Universités, UPMC Univ Paris 6, Université Paris-Diderot, Sorbonne Paris Cité), 4 place Jussieu, 75005 Paris, France. E-mail: david.aubin@upmc.fr.
} 
he was studying the stars and looking upwards, he fell into a pit, and a neat, witty Thracian servant girl jeered at him, they say, because he was so eager to know the things in the sky that he could not see what was there before him at his very feet." 1 As shown by the historian of philosophy Hans Blumenberg (2015), this anecdote occupies a fundamental place in the Western imagination. Not only was stargazing a dangerous occupation for the observer: it simply was not an occupation suited to the common people.

In an incisive analysis of the telescope as a media, the philosopher Joseph Vogl emphasized the instrument's "self-referentiality" in Galileo's hands. By this, Vogl meant that "whoever, along with Galileo, looks at the sky through a telescope is at the same time looking back at him- or herself-seeing is self-seeing, observation is selfobservation, locating is self-locating" (Vogl 2008, 19). Following Blumenberg, Vogl identified a crucial antinomy in telescopic epistemology. On the one hand, the telescope increased the visibility of certain celestial phenomena and gave evidences in favor of the Copernican system. But, on the other hand, "this very evidence is called into question by the telescope-effect: every visibility now bears a stigma of provisonality; every visibility is surrounded by an ocean of invisibility" (Vogl 2008, 22). I believe, however, that Vogl's analysis of the mediating function of the telescope gains a great deal of potency when applied, not to high scientific culture and epistemology, but to the popular practice of astronomical observation. In popular contexts, telescopes were rarely intended as tools for adding to existing knowledge, but as "mediating machines" (Wise 1988) that connected together different realms of culture, namely academic science, nonscientific sociabilities, and popular culture. If we can agree that "the medium is the message," what was the telescope's message in nineteenth-century Paris? What was the epistemology of popular stargazing?

By making invisibility visible, I want to argue, the telescope was especially slippery as a device of public consumption. By granting popular audiences the possibility of peeking through telescopes, some showmen were inviting the public, not just to the spectacle of the sky, but also to the spectacle of science. The process by which scientists discovered scientific truth thus lay bare-or so it surely seemed to some

\footnotetext{
1 Plato, Theaetetus, 174a; trans. Fowler (1921), available online: http://data.perseus.org/texts/urn:cts:greekLit:tlg0059.tlg006 (last viewed July 21, 2016).
} 
observers who clearly perceived themselves as observing the way scientists themselves were doing science. As we shall see, this vulnerability led to another antinomy peculiar to popular science ${ }^{2}$-emphasizing the usefulness of partaking in the scientific movement while ridiculing as often as possible the mediators who allowed the general public to glance at it.

Sources allowing us to document popular scientific practices are notoriously difficult to unearth. Historical studies on science popularization in the nineteenth century have thus perforce often been focused on top-down processes. The popularization of astronomy in particular has received much attention, since some of its most successful writers like François Arago produced works that reached the status of bestsellers. Although exceptional, the 125,000 copies of the Astronomie populaire sold by Camille Flammarion (1880) showed the wide appeal such work could have. ${ }^{3}$ Except for the case of cosmology at the turn of the century (Fages 2012), there has been limited attention paid to popular science writing proper in astronomy, by which I mean texts produced by nonprofessional writers. When we leave texts aside, historical investigation becomes much more difficult and there are only very few practices that can be documented in reasonable detail. ${ }^{4}$ Recent publications (Thébaud-Sorger 2015; NietoGalan 2016) have shown that the study of spectacular science is especially well suited to put the tension between experts and lay audiences to the fore, but little regarding astronomy has emerged.

Much to my surprise, when I set out to investigate the story of street telescopes in nineteenth-century Paris, I realized that I was able to uncover a great deal of material about them. ${ }^{5}$ In the Enlightenment, the "spectacle of the sky" had been a potent metaphor, but it scarcely led to actual observations of the stars and planets, especially among popular audiences. Although the origins of popular stargazing are hard to pinpoint exactly, I uncovered some evidences early in the nineteenth century of telescopes being made available to the public. Later, popular stargazing was associated

\footnotetext{
2 On the paradoxes of science popularization, see Topham (2009); other important reference on the history of science popularization in the nineteenth century are Cooter (1994), Secord (2000), and Daum (2002).

${ }^{3}$ On print-run of popular science books, see Bréguet (1990, 60-61), and on Flammarion specifically, see Parinet (1992), 228 and 376-378.

${ }^{4}$ For a pioneering exception to the lack of attention to popular science practice, concerning the field of popular botany, see Secord (1994).

${ }^{5}$ For preliminary investigations of this topic, see Fonvielle (1889) and Fuentes (1998).
} 
with the rise of nocturnal public street life especially along the grands boulevards where most of the theaters were located in the first half of the century. Unsurprisingly, public telescopes were still mostly seen as simple entertainment. During the Second Empire (1852-1870), street telescopes moved toward the monumental parts of the capital and came to be seen as proper educational tools. With the reestablishment of the Republic after 1870, some public telescopes migrated towards more popular neighborhoods and a popular observatory attracting a wide audience was opened at the Trocadéro Palace in 1880. In conclusion, I discuss the reversal of perception allowed by this popular epistemology and I argue that in the process it was science itself that was placed under the scrutiny of the popular gaze.

\section{The Telescopes of the Grands Boulevards}

On a sunny Sunday of April 1818, seemingly for the first time in the history of Paris, a telescope was publicly displayed in a popular site for anyone to use. In the Northeast outskirts of the capital, a new park had opened where huge slides promised untrodden forms of excitement to the visitor. The Mountains of Belleville [Les montagnes de Belleville] were an attraction located in a park ideally suited for a leisurely stroll in a Romantic setting, where the instrument maker Robert-Aglaé Cauchoix (1776-1845) installed a series of those optical techniques that would forever change the vision of modernity (Crary 1990). There was a large camera obscura equipped with an eight-foot wide screen and periscopic lenses. On a belvedere, Cauchoix installed several telescopes of his invention (named "lunette polyaldes" by him). ${ }^{6}$ Although they seemed mostly to have been used to peek at faraway sights in the city, Cauchoix's telescopes could be used to see sunspots and other astronomical phenomena. In the Belleville Park, a journalist commented:

\footnotetext{
${ }^{6}$ For a description of Cauchoix's exhibit, see the Journal des débats (April 13, 1818); see also La Revue, ou Chronique parisienne, politique, morale, littéraire et théâtrale 3 (1818), 36. For Cauchoix's telescope, see his patent application: "Lunettes à grossissements variables, nommées lunettes polyaldes," IMPI; available online: http://basesbrevets19e.inpi.fr/ 1BA1345. Cauchoix's periscopes were adapted from William Hyde Wollaston and his camera lucida from Giovanni Battista Amici's. See Bazar parisien, ou Annuaire raisonné de l'industrie des premiers artistes et fabricans de Paris (Paris, 1822), 85; and Journal de l'Empire (October 12, 1813), 3. The opening of Cauchoix's shop on the quai Voltaire was advertised in the Journal des débats (December 23, 1814), 1.
} 
one finds a belvedere on which strange mirrors, telescopes, and other instruments were positioned, with which one can see what takes place on Earth and in the sky, sunspots, mountains on the Moon, stars, comets when there will be some.... This is another Observatory where one will be able with little effort to get a complete course of astronomy. ${ }^{7}$

Because of this setting, the status of the Belleville telescopes was ambiguous. Was this an advertisement for Cauchoix's optical devices, mere entertainment, or serious education?

In the 1810s, science in Paris was turned into a street show. "Hey," a commentator mused ironically. "How would science not make quick progress? Savants scour the streets and our boulevards have been turned into physics schools." ${ }^{8}$ For a few sous, strolling families and early Parisian flâneurs could witness several physics and chemical experiments performed "in open air" (en plein vent) and marveled at the way knowledge was now so readily accessible to all. "You can have a physics lesson at the cour des Fontaines" (near the Palais-Royal), wrote some of them, "and you will find a dynamometer and a microscope on the pont des Arts" (Ourry 1818, 135; see also Jouy $1813,1: 284)$. These public physicists and chemists however were, more often than not, poor lads, who could barely make a living with their trade. They went from town to town and divulged "secrets hitherto confined to the sanctuary of science." 9 To a reporter who saw this as a dangerous "profanation" of science, a correspondent of the Journal de Paris countered:

these so-called physicists, these so-called chemists, who for the most part are nothing more than the handlers and operators [of their instruments], can be useful. Indeed, far from gearing people's credulity to a wrong direction, they

\footnotetext{
7 “on y trouve un belvédère sur lequel on a placé des miroirs curieux, des télescopes, et d'autres instruments, à l'aide desquels on peut voir ce qui se passe sur la terre et dans les cieux, les taches du soleil, les montagnes de la lune, les étoiles, les comètes quand il y en aura ; on y voit tout, comme en plein midi. C'est un autre Observatoire où l'on pourra faire à peu de frais, un cours complet d'astronomie." Journal des débats (April 20, 1818), 3.

8 "Hé comment les sciences ne feraient-elles pas des progrès rapides ! les savans courent les rues, et nos boulevards sont devenus des écoles de physique" (Pujoulx 1801, 33-34). On the visibility of science in eighteenth century Paris, see Belhoste (2011).

${ }_{9}^{9}$ Journal de Paris, no. 199 (July 18, 1813), 1.
} 
sometimes put it to right; far from scaring the weak, they comfort them by erasing from their mind the false and childish ideas they had conceived. ${ }^{10}$

Cauchoix's spyglasses were first sold to theatergoers. His achromatic lunettes de spectacles apparently were clearer and had a higher magnifying power then those sold by his competitors. ${ }^{11}$ In 1822, a scheme was imagined to make telescopes permanently available to public users. Only this was not in order to look at the sky, but at theater shows. Seeing that spyglasses used by fashionable Parisians were becoming heavier and heavier, an optical company suggested that telescopes be installed on the balcony of some halls, where members of the audience could buy tickets to peak through them. ${ }^{12}$ It is difficult to know whether the scheme was ever implanted, but soon after telescopes began to sprout outside the theaters.

On clear nights, a private entrepreneur, a "brave man," set up a telescope on the Boulevard Bonne-Nouvelle-belonging to the long series of boulevards that then formed the heart of the Parisian nightlife. According to a reporter who told the story, there was a lot a people who turned up to look at the sky for a few sous while listening to the man's explanations. "The telescope of the boulevard de Bonne-Nouvelle is, every night, surrounded by an affluence of amateurs: one sees there military men, traders, artists, men of letters, who want, each on their turn, to read in the stars."13 Unable to attend the première of a vaudeville show titled La Lune de miel in 1826, a journalist spent the duration of the play "considering the stars that a peddling astronomer [astronome ambulant] shows with the help of a telescope in front of M. Poirson's theater."14 At that time, Charles-Gaspard Delestre-Poirson (1790-1859) was the owner of the Théâtre du Gymnase opened in 1820 on the boulevard de Bonne-Nouvelle. Both journalists quoted

10 "ces prétendus physiciens, ces prétendus chimiste, qui, pour la plupart ne sont que des manipulateurs et des opérateurs, peuvent être utiles. En effet, loin de donner une fausse direction à la crédulité du peuple, ils la rectifient quelquefois ; loin d'effrayer les faibles, ils les rassurent en effaçant de leur esprit les idées fausses et puériles qu'ils s'étaient faites." J. B., "La Science en plein vent, le meunier astronome et mécanicien," Journal de Paris, no. 207 (January 26, 1813), 3-4. On this minor controversy, see also Journal des arts, des science et de la literature 3 (1813), 94.

11 See Journal des débats (December 21, 1815), 3 and (February 15, 1816), 3.

12 See Le Miroir des spectacles, des lettres, des mours et des arts (January 24, 1822), 4. ${ }^{13}$ See Le Diable boîteux: journal des spectacles, des mours et de la littérature (April 8, 1824), 4 and ibid. (June 5, 1824), 4.

${ }^{14}$ Le Figaro (April 1, 1826), 4. 
above may thus have seen the same astronomer. Besides the seemingly short-lived attempt by Cauchoix to exhibit his "lunette polyalde" in Belleville, this seems to be one of the first telescopes offered for public use. ${ }^{15}$

Instrument makers of course needed to make their instruments available to potential buyers. The optician Jean-Gabriel-Auguste Chevalier (1778-1848) installed a rudimentary observatory, equipped with a small refracting telescope, on top of the tour de l'Horloge, on the île de la Cité. Not much is known about this small observatory perched above the Seine, but it seems to have have been open for several decades.

The location is quite exceptional, and people curious to enjoy this agreeable perspective may come to me during the day; they will always find, in case I have some other business to attend to, someone to lead them to the observatory and guide them in the use of the telescope; all this without payment. ${ }^{16}$

Chevallier was famous for his publicity stunts and the great thermometer and barometer he had placed on the façade of his shop were internationally famous. When a great comet became visible in the clear sky of Paris, in September 1811, streets, bridges, and piers were cluttered with amateur observers; some found a better spot in Chevallier's observatory. ${ }^{17}$

In the first decades of the nineteenth century, Paris boasted many opticians, most of which were installed between the tour de l'Horloge and the Pont-Neuf, along what was then known as the quai des Lunettes (earlier quai des Morfondus, today quai de l'Horloge). But up to the 1810 s and early 1820s, few were able to make good-quality achromatic spyglasses. People who had the means usually resorted to importing them

\footnotetext{
15 In the 1820s, optical instruments including telescopes might also have been made available in the Nouveau Tivoli, a popular private park on rue de Clichy like the Mountains of Belleville. But the evidence is hard to interpret. See Le Figaro (November 29,1826), 4.

16 "L'emplacement est très-avantageux, et les personnes curieuses, qui désirent jouir de cette agréable perspective, peuvent se presenter chez moi dans la journée ; elle trouverons toujours, dans la cas où j'en serais empêché moi-même, quelqu'un pour les conduire à l'observatoire et les guider dans l'usage de la lunette; le tout sans aucune retribution" (Chevalier 1815, 671). According to a contemporary amateur astronomer, this kind of observatories installed by telescope makers were mere "simulacra" (Bonnardot 1855, 273).

17 See Journal de l'Empire (September 12, 1811), 3. On Chevallier, see Blancheton (1843), Champagnac (1841, 261-269), and Charrin (1815, 92-95). See also Chevalier (1819). His observatory is still mentioned more than fifteen years later in the Annales du commerce (August 3, 1828), 2.
} 
from England, from the Dollond workshop especially. ${ }^{18}$ In the late 1780 s, Cassini IV at the Observatory tried to impulse the development of high-precision optical business in Paris, promoting Cauchoix in particular. Such efforts were pursued by the successive occupants of the Observatory, who now closely interacted with makers in the Bureau des longitudes. By the end of the 1810s, French makers such as Cauchoix and Noël-Jean Lerebours (1762-1840) were making optical glass and excellent instruments for the Observatory. But instruments adequate to make astronomical observation remained very expensive and out of the reach of the general public. Between 1820 and 1826, the Société d'encouragement de l'industrie nationale, taking notice that the German makers Joseph von Frauenhofer (1787-1823) and Georg von Reichenbach (1771-1826) were now competing with their British counterparts, offered a price to the French artisan who would succeed in making a machine able to grind optical glass. ${ }^{19}$

At that time the price of optical instruments remain prohibitive for private persons with modest means. In 1820, the Chevalier Albert Hennet (1758-1828) was among the rare authors who, in his course on "contemplative astronomy," suggested one might be able to equip an "economical observatory" (Hennet 1820, 65; on Hennet, see Dinaux 1829). A meridian quadrant would only cost the pain of drawing it; one could get a metallic celestial globe for 30 francs, with instructions at $5 \mathrm{fr}$.; a dark glass to observe the Sun was no more than a few sous. "Here is how, with 36 to 40 francs, you will have an observatory where you will be able to gaze at all the marvels of the sky, follow, even predict all the motions of celestial bodies, and do, alone, a full course of astronomy" (Hennet 1820,65). Of course, he added, to acquire a telescope, one would have had, at the very least, to multiply the price, not by two, but by ten. According to a catalogue, a small 12 inches achromatic refracting telescope was already listed at 45 francs; a mounted telescope with magnifying power of 200 would have costed 600 francs (Établissement de Pixii 1824, 27).

18 Dollond started to market achromatic Army telescopes in the 1780s. See King (1955), 161.

19 "Prix pour la construction d'une machine propre à travailler le verre d'optique," Bulletin de la Société d'encouragement pour l'industrie nationale 24, suppl. "Programmes des prix proposes, le 26 octobre 1825" (1825): 7-8. In 1827, the Bulletin published an article explaining that although not completely satisfying this was a step in the right direction: see "Description d'une machine propre à doucir et polir les verres d'optiques, inventée par M. Legey, ingénieur en instruments de mathématiques, rue de la Planche, $\mathrm{n}^{\circ} 12$, à Paris," Bulletin de la Société d'encouragement pour l'industrie nationale 16 (1827): 339-345. 
This is not to say that amateur observation practices could not arise without instruments. To illustrate this, one may look at the short life of Edouard Richer (17921832), who died at forty of tuberculosis. Born on the island of Noirmoutiers, he was barely eighteen when he was struck by a passion for astronomy. A naturalist, he was attracted to the mathematical side of astronomy. "As for me," he wrote "I like to loose myself" in the sky. Contemplating the sky in the countryside near Orvault, he imaged other worlds peopled by other forms of life and of intelligence. "I lost myself to all the sublime ideas that this spectacle usually excited in me, and it elevated me so strongly above our earth that I found myself back on it with a sort of disdain" (Piet 1836, 94-95). To understand the passion of so many of the people discussed here, one should be reminded that astronomy could be a Romantic source of happiness. In his "course of contemplative astronomy," written at a time when he was mourning his wife, Hennet was quite explicit: "You who have been struck to grief, turn your eyes to the sky; up there, everything is beautiful, wise, peaceful; everything is admirable" (Hennet 1820, $\mathrm{xvi})$.

On March 6, 1836, the Journal des débats discussed an incredible piece of news coming from the United States (Donné 1836). The Americans reported that through his large telescope in the Cape of Good Hope John Herschel (1792-1871) had been able to observe the inhabitants of the Moon (covered with long hair and according to their expression more intelligent than orang utans). Following Arago's arguments refuting the claim at the Academy of Sciences, the science journalist Alfred Donné took advantage of this episode to delve into the practice of observation with the help of a telescope. "For that matter," he wrote, "it is not as difficult as one generally thinks to satisfy one's curiosity about the moon and to afford oneself the enjoyment of this fascinating spectacle" (Donné 1836). Without bothering the astronomers of the Observatory, any amateur could observe the mountains on the Moon, Saturn's rings, the moons of Jupiter, double stars, etc. Inviting readers to partake in scientific progress, Donné (1836) emphasized:

if you feel like it, there is no need to be a knowledgeable astronomer nor a profound mathematician to make observations truly useful and beneficial to science. The field is wide open to everyone; scientists reap it with patience and good will; every one of us may glean from it. 
To this end, the great telescopes found in observatories were too expensive and difficult to handle. But for a mere 100 écus (500 francs), Cauchoix could provide amateurs with a two-foot refracting telescope that was the promise of "beautiful nights and delicious moments of contemplation." In the polemic surrounding the Great Moon Hoax, as it was called, critics accused Donné of gratuitously advertising Cauchoix's telescope (Considerant et al., 1836, 31). The journalist countered that he would only be too happy if his article promoted the sales and use of astronomical instruments. The maker JeanBaptiste Soleil (1798-1878), he added, now had a very good telescope for sale at barely 200 francs. $^{20}$ This was cheaper than twenty years earlier, but still much more than most could afford.

The democratization of astronomical observation was thus underway and, slowly, the telescope made its way towards "the hands of the amateurs." 21 Twenty years later, small refracting telescopes whose handling could be easily learned were available, in particular from the makers Lerebours and Soleil. In 1855, the historian Alfred Bonnardot (1808-1884) was among the first to publish a popular book on astronomy completely based on the practice of observation. Using Romanesque techniques, he pictured himself with students in the countryside peeking through telescopes. In his book, Bonnardot issued a plea for the leisurely class to embrace amateur astronomy as a worthwhile hobby. He even imagined that a public observatory could be organized by subscription. Meanwhile, Parisians were offered new ways to familiarize themselves with astronomical observations.

\section{A New Star of the Parisian Night}

On July 30,1840, the poet Heinrich Heine (1797-1856) observed with interest the game of a man who had installed a large telescope on the place de la Bourse. To attract his customers, the man was inspired by the stories told about Herschel in the Cape. The man, according to Heine, told people around him about the great surface of the Moon, its mountains, its rivers, and its distance from the Earth. A couple approached. The husband showed interest in the attraction, but his wife replied that he had better spend his two sous on tobacco and that everything the peddler was telling about the Moon were mere

20 Journal des débats (April 26, 1836), 2. On Soleil, see Brenni (1996).

21 "Le télescope entre les mains d'un amateur." Magasin pittoresque 22 (1854): 191-192; and 223-224. 
fantasies invented as a scam for getting money out of naïve people (Heine 1866, 110111; see also Phelan 2006, 196). For the poet, the story illustrated the strange mixture of skepticism and gullibility one found among the French lower classes. But Heine-who recalled elsewhere being befuddled by the astronomy lessons he was subjected to as a child $^{22}$-showed absolutely no interest in looking for himself in the telescope. Not that he shared the woman's blanket skepticism, but apparently this struck him as mere entertainment, even for the "vulgar."

Having first shown up in gardens and on the boulevard, the public telescopes were still associated exclusively with commerce and entertainment. As such, these installations attracted little notice and it difficult to find written testimonies of the earliest Parisian public telescopes. On September 4, 1829, Le Figaro, then a satirical journal, mentioned in passing "la lunette du Pont-Neuf." It is again in a small passage full of irony that a book reviewer reveals the existence of a telescope on the place Vendôme in $1834 . .^{23}$

Shown on the Boulevards, near the new popular Parisian theater scene, the public telescope quickly became a fascinating trope of the vaudeville theater. As a meeting point between abstruse scientific practices and the wide public, the theme was especially attractive to satirists who mocked both the impenetrability of learned perspectives and the credulity of the crowd that was too eager to penetrate at least a small part of the scientific elite's knowledge. On December 31, 1836, a theaterhouse (théâtre de l'Ambigu comique) staged a character named the "astronomer of the quai des lunettes" in its yearly review (Lajonchère and Clairville 1837). That same year, the théâtre de l'Ambigu comique also had another vaudeville production in which a telescope maker had the leading part (Saint-Firmin 1836). On June 23, 1849, the Théâtre du Vaudeville again portrayed the peddling astronomer of the place de la Bourse mentioned by Heine. The character named "Le Firmament" sang on the famous toon of the nursery song Au Clair de la Lune:

Place de la Bourse

Je fais voir au ciel

Petite et grande ourse

\footnotetext{
22 “je fus tout déconcerté par les leçons d'astronomie, qu'alors, dans la période des lumières, on n'épargnait même pas aux petits enfants" (Heine 1835, 5(1):167).

${ }^{23}$ Revue européenne 8 (1834), 112.
} 
Je dégomme Herschel!

Pour moi point de voiles,

Dans l'ciel éclairci,

J'fais voir des étoiles

Même en plein midi. (Leuven and Brunswick 1849,11)

At this point, hailed by Le Firmament, a character named "Paris" remarked that the telescope had become a familiar site outside the vaudeville theaters. It was as if the city itself acknowldged: "I cannot stop looking at the Moon" (Leuven and Brunswick 1849, 12). As a further indication of the strong cultural presence of streetcorner astronomers, we may also mention a song published in 1844 featuring "the Pont-Neuf's Arago" who promised for just a sou to show the Moon and its forest, its cities, and it people who "live there quietly without kings and city councilors." 24 According to a report from 1842, "it seems that the taste for astronomy is spreading among the Parisian people." Telescopes could be found every night, near the quai des Lunettes, on the Pont-au-Change (in front of Chevallier's workshop and observatory), on the Pont-Neuf, and at the place du Châtelet. ${ }^{25}$

As the sight of public telescopes became increasingly familiar, images started to crystallize concerning the showman and its public. The street astronomer generally remained nameless, more or less ignorant and usually heavy-handedly exaggerating the appeal of his attraction. As an observer of the Parisian street life wrote, the showman "delivered, in front of an ambulant telescope, elementary notions of Arago and Herschel's science, in the rather unseemly form of a more or less melodic recitation."26 The public was numerous, but credulous and even more ignorant than the telescope handler. Although it was cheap, the attraction was perhaps not worth its price and the

24 "L'astronomie / Charme la vie / Approchez-vous, rien n'est si beau ; / Du Pont-Neuf je suis l'Arago / Messieurs, à mon observatoire / Les places sont au grand rabais, Un sou ! c'est à ne pas y croire / Pour voir la lune et ses forêts [...] / Vous y verrez de grandes villes, / Des hameaux mais point de châteux ; / Les peuples y vivent tranquilles. / Sans rois et sans municipaux." Vincens, "L'astronome du Pont-Neuf: air de la Treille de sincérité" in (Gille 1844, 2:238-240). Let us point out that Arago was active-and contested-as a city councilor of Paris at the time.

${ }^{25}$ See Le Cabinet de lecture et le cercle réunis: gazette des familles 13 (1842), 472. The telescope of the Pont-Neuf and place de la Bourse are also mentioned in Caraguel (1850).

26 "débiter devant un télescope nomade les notions élémentaires de la science des Arago, des Herschell, sous la forme assez malséante en pareil cas d'un récitatif plus ou moins musical" (Kastner 1857, 107). 
peddler was often miserable. Like other street attractions, it moreover exposed its adepts to petty theft. A newspaperman told the story a poor domestic fooled by a dishonest onlooker who stole her things while her attention was distracted by the unfamiliar sight of the "great ball of fire." 27 Thus were common tropes about the astronomer's distraction reinvested with new meanings when the popular gaze met the telescope. But, like astronomers, the crowd was not just distracted by the telescope and attention was geared towards the gain of knowledge.

\section{Astronomers in the Street vs. the Observatory}

More and more, as the experience of the telescopic vision spread in Parisian society, astronomers in the wind were seen as providing a valuable service to all classes. By 1860, famous traveling guidebooks mentioned the telescope of the Pont-Neuf, in front of the statue of Henri IV, as a worthwhile attraction for the tourist passing through the French capital (Baedecker 1860, 100). None of the previous mediations of astronomy disappeared. As is well known, the 1850s on the contrary saw the rise of a proper, highly segmented market for the popularization of science in general, and astronomy in particular. The sale of books, journals, paper charts, and models skyrocketed, while public lectures were more popular than ever. The possibility of directly witnessing the spectacle of the heavens however was a novelty that started to change both the public and professional perception of astronomy.

For the elite, just looking through the telescope was clearly not enough to provide a proper idea of astronomy. In his memoirs, the naturalist Armand de Quatrefages (1810-1892) underscored the ridicule of those who claimed to acquire in this way a proper feel for a scientific domain: "to judge zoology and botanics through the volumes of small anecdotes that have made the delight of our youth is like judging physics through the tricks of a prestidigitator and astronomy through what one knows of it when one has only watched Saturn's ring and the mountains of the Moon in an open air telescope."28 Clearly, as a newspaperman ironically recounted, not much knowledge was

${ }^{27}$ See Le Cabinet de lecture et le cercle réunis: gazette des familles 13 (1842), 472. A similar story of a man robbed while peeking through the telescope on place de la Concorde is also told in Le Petit Journal (September 21, 1868), 2.

28 "juger de la zoologie ou de la botanique par les recueils d'historiettes qui ont amusé notre jeune âge, c'est juger de la physique par les tours d'un escamoteur, et de 
to be gained from such undisciplined observation. Indeed, naive people looking through the telescope might merely observe their own eyelashes. ${ }^{29}$

Slowly, however, the public telescope started to be seen as an instructive first step toward more substantial knowledge of astronomy. The astronomer of the place Vendôme was featured in Gustave Flaubert's (1821-1880) famous novel Bouvard et Pécuchet (Flaubert 1881, 97). And although Flaubert's novel was also a satyre about the vanity of popular knowledge, the street telescope that provided Pécuchet with his first exposure to astronomy put him on the way to positive knowledge, sure facts, and solid figures about the solar system and the Galaxy.

In June 1858, a comet was discovered by the Tuscan astronomer Giovanni Battista Donati (1826-1873), and by September of that year, it filled a large portion of the sky above Paris. This unusual phenomenon seems to have played a catalyzing role in changing the perception of the street astronomer.

For the last few days, Paris has been excited. At eight o'clock, considerable crowds occupy piers and squares, and look at the sky trying to see the comet which shows up at this time. On the place du Pont-Neuf, two immense telescopes have been set up and they hardly suffice to satisfy all the curious people eager to admire the hairy star. ${ }^{30}$

On October 3, 1858, Le Figaro reported on popular observers on the place du Carroussel, near the Louvre. The public astronomer's speech was reproduced in the article, as well as questions from the crowd. The telescope handler attracted his clients with a technical speech specifying the distance of Donati's comet from the Earth. Taking advantage of his sudden rise in popularity, he had doubled his price to 4 sous. Mocked by the kids and attracting the bourgeois, the street astronomer however guaranteed that there was no

l'astronomie par ce qu'on en sait, quand on a regardé l'anneau de Saturne et les montagnes de la Lune dans une lunette en plein vent" (Quatrefages 1854, 1:vi). 29 "De temps à autre, au pied de la colonne [Vendôme], il se forme un groupe curieux. L'homme au télescope fait admirer les étoiles ou la lune aux passant qui clignent des yeux et n'aperçoivent guère que leurs cils sur la lentille" (Claretie 1867, 1405). 30 "Depuis quelques jours, Paris est en émoi. Dès huit heures du soir, une foule considérable encombre les quais, les places, regardant le ciel et cherchant à voir la comète qui apparaît à cette heure. Sur le terre-plein du Pont-Neuf, on a établit deux immenses lunettes, et il y a peine à satisfaire tous les curieux avides de contempler l'astre chevelu." La Presse (September 17, 1858), 2. 
need to have studied astronomy to see the comet through the telescope. ${ }^{31}$ Before the end of the year, a play featuring an optician with his telescope was performed at the Théâtre des Variétés (Cogniard and Clairville 1858).

In 1860, another comet could again be seen in the Paris sky. Several Sundays in a row, a public lecture at the great amphitheater of the Faculty of Medecine by the professor at the Collège de France Jacques Babinet (1794-1872) about the comet drew a large crowd filling up the seats two hours for the start of the talk. Each of these occasions, it was emphasized, also "made the fortune of the exhibitors of the sky" [montreurs d'astres] (Martin 1860, 7). At the Paris Observatory, however, the director Urbain Le Verrier (1811-1877) was annoyed by all the requests he was receiving to observe the comet. On October 29, 1858, he wrote to Donati: "Since the comet has become visible to the naked eye, a crowd of journalists-astronomers has gathered here in Paris, publishing the most fanciful observations and the most extravagant theories. We have then been forced to keep a reserved attitude, compatible with serious science" (quoted in Gasperini et al. 2011, 340.) Thus, the Observatory created a void at a time when people were eager for answers and to see the comet for themselves. The radical scientist François-Vincent Raspail (1794-1878) criticized this attitude pointing out that street astronomers rendered a useful service to the population:

As for the gentlemen of the official observatories, they wrap themselves in the dignity of their silence and rely on the zeal of open-air astronomers who, with no other observatory than the street, always have an influx of listeners and viewers for a modest price; the university goes away, science runs in the street. ${ }^{32}$ Building on this popular demand for instruction and distraction, peddling astronomers now turned public telescopes into installations that could be taken seriously.

\footnotetext{
${ }^{31}$ For another fanciful description of the Pont-Neuf astronomer at this time, see Le Monde illustré 3 (1858), 230.

32 "La comète a eu pour observateurs tous ceux qui ont le bonheur de n'être pas aveugles. Les astronomes, à qui mieux mieux, s'empressent de dire toutes les semaines dans les journaux, et en termes techniques, tout ce que chacun à vu avec son gros bon sens [...]. Quant à MM. des observatoires officiels, ils s'enveloppent dans la dignité de leur silence et s'en reposent sur le zèle de MM. les astronomes en plein vent, qui, n'ayant d'autre observatoire que la rue, ont toujours affluence d'auditeurs et de voyants à un prix modeste ; les universités s'en vont, la science court les rues" (Raspail 1858, 120).
} 


\section{Le Verrier's “Colleagues"?}

Among the astronomers in the wind, some acquired a greater fame under the Second Empire (1852-1870). Installed for at least two decades, respectively, on the place Vendôme and on the place de la Concorde (further, that is, from "gay Paris"), they offered a service that was now seen as more than cheap entertainment. For the writer Edmond Texier (1815-1887), peddling astronomers counted among the "small industries" mushrooming in the industrial capital. In Haussmann's Paris, the police tried to repress the informal economy, but in Texier's opinion the authorities needed to tolerate "the Galileo of the place Vendôme" as a public good (Texier 1867, 2:964-965). Covered with a long "Polish" overcoat and wearing a "Greek" hat, the figure he painted of the astronomer was quaint. ${ }^{33}$

Who was this strange man? It is difficult to identify him for sure. A journalist in 1872 wrote that his name was Billault; another that it was Billant. Others called him "\textit\{le père Jupiter."34 All evidences seem to point to the fact that the astronomer of the place Vendôme was the same man for at least a decade and probably more than that. On March 1, 1879, Le Monde illustré wrote that an astronomer had been practicing on the place Vendôme for the last 35 years, which would mean that the first telescope was established there in the mid-1840s. This man was described an an "old peddler" [vieux mendiant] by the poet Aleksandr Herzen $(1870,123)$. His poor appearance was in stark contrast with the presumed worth of his telescope, "which represent[ed] all of his wealth and which he carried around in a wheelbarrow specifically designed" for this purpose. Nobody seemed to know where the man had come from: "he is a loner, a misanthrope; his manners were proud and reserved, his attitude simple and austere like a savant, his look recalled Diogenes." 35 Some said that he had later made enough to set up an optical shop near the Invalides (quartier du Gros-Caillou) and was still showing

\footnotetext{
33 For another description of the astronomer (however this time located at the PontNeuf), see Texier (1852), 1:245.

${ }^{34}$ Alexandre Flan, "Les astronomes," Journal amusant, no. 63 (March 14, 1857), 5.

35 "Dès que le ciel est clair, l'atmosphère limpide, il arrive là avec un énorme télescope qui représente toute sa fortune, et qu'il traîne à bras sur une brouette façonnée expressément. Cet homme habite on ne sait où ; il est solitaire, misanthrope; il a des façons fières, recueillies, la tenue simple et austère d'un savant, des allures de Diogène." Le Monde illustré (January 18, 1862).
} 
his telescope in the parc de Saint-Cloud, on the platform of the Lanterne where there is a nice view over Paris. ${ }^{36}$

Whatever his fortune, the street astronomer started, in the late 1850s, to be deemed a respectable introduction to the marvels of science. This man is not a mere "entertainer" [saltimbanque], emphasized a journalist. Only someone with sure and expert hands could unveil the mysteries of the sky to the public. ${ }^{37}$ By the 1860s, a visit to open-air astronomers could even be recommended for the enlightenment of children. ${ }^{38}$ The pastor A. Hugues who was working for the Science Section at the Ministry of Public Instruction imagined the story of a widow who took her children not only to the Observatory (to which, as we shall see, Hugues could get access as a member of Le Verrier's Association scientifique de France), but also to pay a visit to the astronomer of the place Vendôme.

Who of you, my dear readers, if you have live in Paris, has not seen the place Vendôme and its imposing column? ... At the very foot of the monument, ... there is every day and every evening when the weather is clear an astronomical telescope set up on the ground, turned toward the sky and through which in exchange of ten or fifteen centimes an old astronomer offers to bystanders a spectacle as interesting as it is affordable. ${ }^{39}$

From there, it was a small step to imagine that even professional astronomers could be introduced to their trade on the public square. In the early 1870s, when after his scandalous demission from the Paris Observatory, Le Verrier's figure became highly

\footnotetext{
${ }^{36}$ See Le Monde illustré (March 1, 1879). However, the telescope of the place Vendôme was still mentioned in tourist guides from the 1890s (Martin 1890, 26).

37 “L'homme qui fait voir la lune n'est pas un saltimbanque, un montreur de curiosités quelconques. Le ciel choisit ses cicerones, les belles étoiles qui se voilent de nuages, ne donnent la clef de leur alcôve d'azur qu'à des main sûres et exercées. Il jouit depuis vingt ans du privilege de rappeler qu'il y a un firmament à bien des gens qui l'avaient quelque peu oublié." Le Petit Journal (February 19, 1869), 1.

38 This trope is repeated in the visit to the Bastille telescope by three children (Flammarion 1887, 179).

39 “Qui de vous, chers lecteurs, si vous avez habité Paris, n'a vu la place Vendôme et sa colonne imposante ? [...] Au pied même du monument [...] se trouve presque tous les jours de beau temps et les soirs des nuits sereines, une lunette astronomique installée sur le sol, braquée vers le ciel, et dans le tube de laquelle un vieil astronome offre aux passant, moyennant la somme de dix ou de quinze centimes, un spectacle aussi intéressant qu'il est peu dispendieux" (Hugues 1868, 1-2).
} 
controversial, some satirical writers thus found plausible to imagine him getting his training from a street astronomer:

At night, he used to stroll the place de la Concorde and was having orgies of openair telescope. Every day, the fellow who rented the instrument to the passers-by had terrible quarrels with the young scientist who claimed that, for his two sous, he had earned the right to monopolizing the telescope for 3 hours. ${ }^{40}$

Although the astronomer of the place de la Concorde-obviously-did not train Le Verrier, neither was the satire a complete fiction. Some prominent amateur astronomers indeed greatly benefited from their interactions with street astronomers. The case of the composer Camille Saint-Saëns (1835-1921) is extremely interesting in this regard. As he recalled later, Saint-Saëns (1911) was struck by a passion for astronomy at the age of $24 .{ }^{41}$ Unskilled in mathematics, he was attracted to the observational side of astronomy. Having been introduced to the amateur Hermann Goldschmidt in his small observatory near the place de l'Odéon, he also saw the moon through the telescope of a family friend, the poetess Mme Amable Testu (herself a friend of Arago's). But Saint-Saëns was disappointed: “I did not understand much of what I saw; I had been promised mountains, and these mountains seen from above as they are perceived by birds and aviators at first take by surprise those who on earth have only seen them from the side" (Saint-Saëns 1911, 418). Spotting a copy of Arago's Popular Astronomy in a shopwindow, he immediately acquired the book that wetted his appetite for more sustained observations. The public telescopes of Paris would provide him with the occasion of satisfying his curiosity:

Nocturnal Paris, at this time, was not inundated with light as it is now, and stars could be seen rather well. On the place Vendôme, on the place de la Concorde, on the Pont-Neuf, men displayed large refracting telescopes where one was able, for

\footnotetext{
40 "Le soir, il allait se promener sur la place Concorde et faisait des orgies de télescope en plein vent. Le bonhomme qui louait cet instrument aux passants avait chaque jour des querelles terribles avec le jeune savant, qui prétendait que, pour ses deux sous, il avait le droit d'accaparer la lunette pendant 3 heures. Comme déjà, à cette époque, il avait le caractère aimable d'un homme qui fait six lieues dans s'asseoir, avec des bottes trop justes, quand le vieux au télescope le priait de se retirer pour faire place à d'autres clients, il tapait dessus à coups de parapluie en lui répondant : 'Fichez-moi la paix? Estce que je ne vous l'ai pas payée, la location de votre trombone vitré?'..." Touchatout [Léon-Charles Bienvenu], Le Trombinoscope, no. 62 (November 1872), n.p. 41 On Saint-Saëns' astronomical practice, see Houziaux (2012), 12-17.
} 
two sous, to put his eye and see under a strong magnification the main curiosities of the firmament. Such were our observatories, when the Parisian sky, so often troubled by the mist rising from the Seine, allowed it. 42

Thus introduced to the pleasures of astronomical observation, Saint-Saëns longed for his own instrument. Having sold six pieces for piano and harmonium he acquired a small telescope form Secrétan in time to see Donati's comet through it.

In his memories published in 1911, Saint-Saëns underscored the change in mentalities that had taken place since, at at time when his passion for astronomy was met with utter incomprehension. Since then, he wrote, "Camille Flammarion has brought the stars into fashion and no one is now surprised to see amateurs own a refracting or reflecting telescope." 43 Saint-Saëns indeed was not alone in having been introduced to telescopic observation by the street astronomer at the foot of the column Vendôme. The revolutionary engineer Maxime Vuillaume (1844-1925) was, like Flammarion, very interesting in the popularization of science. A graduate from the elite \'Ecole des mines, in Paris, he nevertheless recalled how he was in his youth "one of the most conscientious visitor and client of the astronomer of the place Vendôme." 44

The peddling astronomer who had established his business on the place de la Concorde may have been even more respected than Billault. Rigal, as he was named, received the visit of a 15-years old Camille Flammarion (1842-1925) in 1857. More than half a century later, the famous science popularize recalled that, even while employed at the Observatory, he was impressed by the observations he could make with the help of Rigal's telescope. The street astronomer, he added, "knew his sky very well” (Flammarion 1912, 160; 1918, 384).

\footnotetext{
42 "Le Paris nocturne, à cette époque, n'était pas inondé de lumière comme à présent, et les étoiles s'y voyaient assez bien. Sur la place Vendôme, sur la place de la Concorde, sur le Pont-Neuf, des hommes exhibaient de grandes lunettes où l'on pouvait, pour deux sous, appliquer son œil et voir sous un fort grossissement les principales curiosités du firmament. Tels étaient nos observatoires, quand le ciel parisien, si souvent troublé par les brumes de la Seine, voulait bien le permettre. C'était avec ces instruments que j'assouvissais les appétits excités par la lecture assidue du livre d'Arago. Mais j'eus bientôt compris que, pour voir quelque chose à la voûte céleste, il est indispensable d'avoir constamment un instrument à sa disposition, cet instrument fût-il d'une médiocre puissance" (Saint-Saëns 1911, 419).

43 "Camille Flammarion a mis les étoiles à la mode et l'on ne s'étonne plus de voir des gens étrangers à la science posséder lunettes et télescope" (Saint-Saëns 1911, 419). ${ }^{44}$ See Le Radical (July 14, 1891).
} 
In a famous book titled A Scientific Voyage Around my Room, the science popularizer Arthur Mangin (1824-1885) devoted a few pages to Rigal's setup and recounted a strange anecdote about him (Mangin 1862, 365-370). This was a clear night in October 1857 and the full Moon was shining over Paris. Passing through place de la Concorde, two men stopped their car and went straight to Rigal. One of the men, who was tall and blond, introduced his companion to Rigal: "This is a colleague of yours, from Saint Petersburg, who is showing the Moon on a bridge over the Neva." Looking at Jupiter through the telescope, the blond-haired man asked what were those shinny balls? "Monsieur, Rigal magisterially replied, these are the satellites of Jupiter. The one you see nearest to the planet was eclipsed just a moment ago; you are the first to see it reemerge." ${ }^{45}$ After some time, the two men revealed their true identity to Rigal. They were the directors of two of the biggest observatories in the world, in Paris and Pulkovo, respectively: Le Verrier, the blond man, and Otto Whilhelm von Struve's (1819-1905). The latter started to quizz Rigal, asking the peddling astronomer to show him the star Vega (whose parallax Struve has just been able to determined) and the 61st star of the Cygnus constellation. Passing this test with flying colors, Rigal had the satisfaction of being called a "colleague" by two of the strictest observatory directors, both infamous for the severe treatment they inflicted on their personnel.

True or not, Mangin's vignette shows that Rigal could be taken seriously by amateur astronomers. Some, like the journalist Lecouturier, frequented Rigal's telescope with assiduity. Experienced observers of the sky suddenly felt entitled to criticize other forms of representation of the heavens. In 1860, a Hamburg showman, A. Rohde, exhibited large projected images of the solar systems, in fashionable astronomical soirées, showing the motion of celestial bodies around the sun, the cause of tides and eclipses, the motion of comets, and the telescopic appearances of the Moon, planets, and the Sun. A journalist, called Lucien Platt, dared to question Rohde's plates for their imprecision on the basis of what he had seen of the Moon with the help of Rigal's great telescope. ${ }^{46}$

45 “Monsieur, répond magistralement l'astronome de la pace de la Concorde, ce sont les satellites de Jupiter. Celui que vous apercevez le plus près de la planète était éclipsé il y a un instant ; vous êtes le premier qui l'ayez vu reparaître" (Mangin 1862, 374). 46 "Quand on a seulement vu la lune avec la grande lunette de Rigal, l'astronome de la place de la Concorde [...], on trouve trop à reprendre dans le tableau de M. Rohde." Lucien Platt, "Bulletin scientifique," La Science pittoresque (September 26, 1860), 168. 
Rigal's and Billault's colleague at the Pont-Neuf was sometimes held in high regards, too: "Stop your carriage here, my grave Academician, and talk with this learned professor, and see how little you really know of the sciences of which you claim to be so bright a light. Talk of theories, this man has his head full of them, and as for practice, why he wouldn't give his telescope for twenty of the big instruments that are guarded with so much care in the Imperial Observatory" (McCabe 1869, 508). Others however painted the man on the Pont-Neuf as rather poor lad. Originally a carpenter, he was said to have been attracted to astronomy by the sight of a meteor shooting through the sky of Montmartre where he was out drinking. The man who smoke bits of tobacco he found on the bridge barely earned three to six francs per night depending on the weather, which he mostly spent in nearby wineshops (Dumonteil 1867).

The news of the Pont-Neuf astronomer's death was reported by several newspapers, first by mistake in 1872, and correctly around May 2, 1875. According to the reports published on these occasions, his name was Jules Bocquet and was know in town as "le père La Lune." Newspapers reported that he was around 88 years old at the time of his death and living in a modestly furnished room in the nearby rue Boutebrie. "Arago and I both are true friends of the sky," Bocquet used to say about the famous popularizer who was his contemporary. ${ }^{47}$ Posted for a long time by the statue of Henri IV, Bocquet had also been seen place Vendôme and, lately, at the pont Notre-Dame. Most of Bocquet's clients were foreign tourists who reportedly were "less blasé than Parisians." ${ }^{48}$ After his death, the press was full of praise:

Father La Lune was a popularizer [vulgarisateur].... While your eye was at the telescope, he would give you a full course in astronomy. This brought him much more prestige than money, since while a few curious persons would spend ten

For a description of Rohde's plates, see Cosmos 17 (1860), 429. This type of shows remained on the bill for a rather long time and was picked up by Robin in 1863. See "Photographie vitrifiée," Les Mondes 1 (1863), 480. On Robin, see Vanhoutte \& Wynants in this special issue.

47 See Le Rappel (March 3, 1872). In this short article, the newspaper announced his death by mistake. In a subsequent issue, they corrected their mistake. See Le Rappel (May 22, 1872). There is also a mention of the père La Lune's death around May 2, 1875 in Dabot (1903-1905), 1:84.

${ }^{48}$ Le Figaro (March 5, 1872), 1. 
centimes, there were plenty of bystanders who without spending a penny would follow with the naked eye the open-air astronomer's demonstration. ${ }^{49}$ A fixture of the Parisian nightlife, surprisingly knowledgeable, yet full of eccentricities, the peddling astronomer was a figure who was fondly used and reused by journalists, playwrights, and novelists. Besides novels like Bouvard et Pécuchet, several plays mentioned the astronomers of the Pont Neuf and the place de la Concorde in those years. On February 18, 1869, for example, a musical comedy inspired by the astronomer of the Pont-Neuf opened at the théâtre des Variétés. It was composed by Émile Durand with lyrics by Jules Moineaux; a piano version was arranged by Isaac Strauss, but all this had little to do with astronomy. At the théâtre du Châtelet, the year review in December 1869 included a sketch about the astronomer of the Pont-au-Change. ${ }^{50}$ This strong cultural imprint reflected their fascinating but ambiguous social position between streets and stars.

\section{Do Stars Speak for Themselves?}

A closer look at the practical sides of the street astronomer's trade is helpful to further unpack their ambiguous social status. Open-air astronomers needed to keep apace with the development, not only of science but also of observation technologies. These instruments were also quite expensive in regards to the benefit one would expect from their exploitation. A case involving Rigal allows us to document the economic side of the business. ${ }^{51}$ Around 1856, the astronomer of the place de la Concorde noted a sudden drop in his clientele and concluded that the competition from the place Vendôme was hurting his business. Billault had apparently installed a bigger telescope than Rigal's and was now drawing a larger crowd. But Rigal could not himself afford such an instrument. An optician named Pierre Queslin (ca. 1808-1882), whose shop was established rue de la Bourse, agreed to lend Rigal a better telescope in exchange for half his earnings. ${ }^{52}$ For

${ }^{49}$ Le Figaro (May 5, 1875). See also Le Rappel (May 7, 1875) and Dabot (1903-1905), 1:84. Let us also note that the death of another astronomer named Cyprien and practicing on place de la Bastille: Le Rappel (August 30,1877), 2 and Le Petit Parisien (September 1st, 1877).

50 Journal des débats (January 1, 1870), 1 and Le Théâtre illustré 2(57) (1869), 2.

51 The following is based on an article published in the Journal des débats (February 19, 1863).

52 Like Chevallier, Queslin was known for his meteorological instruments displayed in his window for the general public. In the 1880s, this data was regularly published by the 
a few years, the agreement worked well. One year, the optician collected 1,700 francs from Rigal. In 1861, however, a British customer who was in the habit of coming almost every night asked to buy the telescope and Rigal directed him to Queslin. The sell did not take place, but in the process Rigal figured out that since 1856 he had, for all practical purposes, already paid the full price of the telescope. Rigal thus unilaterally decided to stop making his payments to the optician.

After losing his trial against Queslin, Rigal resolved to change his telescope for a new one whose specifications were subjected to the scrutiny of the famous science popularizer François Moigno (1804-1884). The objective lens with a diameter of 7.5 inches was made in the workshop of Sautter and ground by Cauche. ${ }^{53}$ The telescope was built by Le Loutre, fils, and mounted on a stand made by Cauchoix, which was very easy to handle (Moigno 1863). With his precious new toy, Rigal suddenly felt entitled to step on serious astronomers' turf. Priding himself of his role as "science critic," Moigno made sure to remind Rigal of his proper place:

Disoriented by the enthusiasm of his happy acquisition, and overstepping the limits of his domain, M. Rigal dared to contest, in a letter we will forget, the existence of the satellite of Sirius and the nebulosity of the Pleiads. To punish him, we will beg M. Goldschmidt to go teach him to see what he will later be able to show. It is not sufficient to want to see [something] to be able and to know how to see. 54

As opposed to the amateur of the Odéon, Hermann Goldschmidt, who had established his reputation by discovering several unknown asteroids, Rigal was not able to convince

daily press, like Le XIXe siècle, Le Figaro, Le Temps, Le Rappel, etc. When Queslin died, in 1882 , a newspaper reported that this practice was at least thirty years old. The first mention I found was in Le Petit Journal (December 11, 1867), 2. At the time of death, Queslin was 73 years old. He had started to work as a simple worker for Baron and bought the Chevalier workshop (not necessarily the same as above) in 1840. See Gil Blas (January 30, 1882), 1.

53 This might be the optician François Cauche (born ca. 1803) who had a working on rue Saint-Martin or his successor. Especially renown for the making of lighthouses, Louis Sautter had a workshop on avenue Montaigne.

54 “Égaré par l'enthousiasme de sa bienheureuse acquisition, et dépassant les limites de son domaine, M. Rigal a osé contester, dans une lettre que nous oublierons, l'existence des satellites de Sirius et de la grande nébulosité des Plél̈ades. Pour le punir, nous prierons M. Goldschmidt d'aller lui apprendre à voir ce qu'il pourra plus tard montrer. Ne peut pas et ne sait pas voir qui veut ; M. Goldschmidt l'a cent fois prouvé" (Moigno 1863, 252-253). 
observers like Moigno that he light be legitimate as a contributor to science. "Stars speak for themselves," Bocquet, the Pont-Neuf astronomer, once answered, when asked how he was able to tend to the demands of the foreign tourists who spoke so many different languages. ${ }^{55}$ By emphasizing the crucial role played by the mediator, Moigno on the contrary underscored the limits of an emerging popular epistemology of observation.

To become an effective way toward scientific knowledge, this popular epistemology had to be properly framed. The open-air telescope handler was not only letting the public see through his instrument; he also was supposed to teach astronomy through the eyes. The props he used to draw his clients and explain astronomical tidbits sometimes attracted more attention than his instruments. To a witness, the pavement of the place Vendôme around the astronomer looked like an open blackboard: "Sometimes, he draws on the pavement some fantastic cosmography at which surprised bystanders look in awe." 56 According to another testimony, the man on the place Vendôme had billboards where he wrote "Tonight, the Moon" or "Every evening starting at 4 pm, Jupiter and its satellites." 57 Another trade was born, taunted another journalist: "To sketch on the asphalt the billboards of the capital's telescopists.... This is the Flammarion of sidewalks and the Perpetual Secretary of the Observatory of the passersby." 58

The astronomer's commercial speech was easy to mock. On December 30, 1865, the Journal amusant ran a full satiric article about the astronomer of the place Vendôme, who mechanistically repeated: "The Moon is forty-nine times smaller than the Earth.... It is eighty-five thousands leagues away from us." 59 Various members of the public steering at the Moon and at Saturn were each and every one of them pictured in ridiculous ways. From the stingy bourgeois who refused to pay the full price because he was disappointed at what he saw to the young couple dreaming of charming tiny Selenites and the drunkard who would not be fooled by what he thought was merely a

\footnotetext{
55 Le Figaro (March 5, 1872), 1.

56 "Parfois il dessine à la craie, sur le bitume, quelque fantastique cosmographie, et les badauds, étonnés, admirent" (Claretie 1867, 1405).

57 Le Petit Journal (December 28, 1868).

58 “C'est de crayonner sur l'asphalte les affiches pour les télescopistes de la capitale. [...] C'est le Flammarion des trottoirs et le Secrétaire perpétuel de l'Observatoire des passants." Le Figaro (October 31, 1877), 2.

${ }^{59}$ Louis Leroy, "L'astronome de la place Vendôme," Journal amusant (December 30, 1865): 2-3 and 6.
} 
trick, the whole panoply of the Parisian society was made to look ridiculous at eyepiece. In the press, the open-air astronomer regularly gained the reputation of a trickster. In 1870 , a telescope handler was almost killed by the angry mob when it was found that the besieging German troops he was charging gullible customers to see turned out to be no more than cutout cardboard figures. ${ }^{60}$ In many cases indeed, the telescope was of course pictured as an instrument with which to see what one was not supposed to see: an infidel wife in Moineaux's play (no date) or holes on the moon promised to gullible investors in Henri Rocherfort's satiric Charivari. ${ }^{61}$ All these were caricatures of course. But in this new regime of observation, instead of caricaturing the telescopic view as a distorted perception of reality, it was now the caricature itself that could be likened to telescope: caricature's "procedure, like that of the telescope, is to magnify the object and show it through a distorting lens."62

As Vogl (2008) has noted, the telescope allowed observers to observe the act of observation itself. In the hand of the early-modern savant, this challenged old epistemologies and was instrumental in the launch of the scientific revolution. When the public eye started peeping through the telescope, established science commentators made sure to explain that a similar contestation of established knowledge was out of the question. Applied to the public gaze, telescopic vision was tamed: it was not as a threat to established order, but a practice that both seemed a bit ridiculous and an essential step toward a proper understanding of contemporary science and epistemology.

At the Observatory, Le Verrier was soon forced to cave in to the public demand for peeking at stars and, by 1864, made it work in his favor with the foundation of the Association scientifique française. More than 3,500 people subscribed in the first year and their contributions were used to fund Le Verrier's researches (Anonymous 1864). In exchange, fancy soirées, where lectures were systematically complemented with public experiments, were organized at the Sorbonne, at the Conservatoire des Arts et Métiers, and at the Observatory. On August 1st, 1864, a much fainter comet, again discovered by Donati, could be observed by the privileged members of the Association scientifique

60 The anecdote was reported in Ernest Blum, "Zigzag dans Paris," Le Rappel (September 29, 1870), 2.

${ }^{61}$ See Les Coulisses (May 9, 1860), 2-3.

62 "son procédé comme celui du télescope grossit et montre l'objet comme à travers une lentille expansive." L. de Cormenin, “De la Caricature," La Liberté (10 February 1850), trans. Hannossh (1992), 76. 
from a large telescope on the roof terrace of the Observatory. ${ }^{63}$ Over the next years, instruments were once a month placed at the members' disposal, "with the necessary explanations" to allow them to see the astronomical events of the season. ${ }^{64}$ Guests at the Observatory soirées had the distinctive opportunity of observing features of the night sky that street astronomers could barely show: a crater of the Moon in all its depth, the polar caps or Mars, the triple star of Andromeda including a faint blue one, etc. (Navery $1864,564)$. Tapping into the public interest for astronomy compounded in part by street astronomers, Le Verrier however fell victim to his success. Since hundreds of people showed up, access to the instrument was restricted. ${ }^{65}$ In a clear allusion to their colleagues working in the street, the astronomers employed by the Observatory rebelled and expressed their resentment at being turned into, "exhibitors in black suits and in the open air."66 Professional scientists seemed to have welcome popular stargazing, but some mechanisms needed to be developed to keep this practice within proper bounds.

\section{Concluding Remarks: The Epistemology of Popular Stargazing}

The "astronomer in the wind," as we have seen, became a prominent cultural figure of the popular science landscape in nineteenth-century Paris, straddling the worlds of science, satiric theater, and journalism. Although this figure has rarely been studied as such, the allusions made to it in popular science literature and above all in the press were quite numerous. Trying to consider this corpus of sources as a whole, one might start to delineate the ways popular observation of the heavens was generally construed at the time. Paying attention both to what these sources are saying and what they imply, usually through a thick layer of irony, I have wished to argue that we may outline a true epistemology of popular observation, at least as far as the heavens are concerned.

Behind the satire, we may recognize a new epistemology of public observation that was put forward in these literary tropes. The public was invited to repeat Galileo's gesture, as was recognized by the Utopian Socialist and science popularizer Henri Lecouturier (1819-1861), "astronomy becomes very interesting and quite sublime to those who, instead of studying it with the mathematicians' algebraic formulas, have only

\footnotetext{
${ }^{63}$ La Science pittoresque 9 (1864), 157.

${ }^{64}$ La Science pittoresque 9 (1864), 336 and 395; Le Temps (June 6, 1865), 2.

65 Cosmos 3 (1866), 609.

66 "démonstrateurs en habit noir et en plein vent." Cosmos 2 (1865), 256.
} 
studied it in the great book of the heavens, [which] is open to all." 67 To understand the full implications of the epistemology of popular stargazing, Lecouturier to whom we owe the anecdote about Le Verrier and Struve might be our best guide (Mangin 1862, 373). Enthralled by Rigal's telescope, which he had used to produce the large lunar map that was featured in Jules Verne's famous Around the Moon, Lecouturier wrote:

the Parisan population, loves astronomical observations; a demonstration [of this fact] is the number of telescopes to be seen set up in the middle of public squares, on bridges, on piers and in all the places where the amplitude of the horizon can be observed. On clear, beautiful nights, all of them are besieged by the crowd [who is] eager to admire the marvels of the sky. Some have a very small aperture; some do not work with a high magnification, and only provide imperfectly focused images; but all reveal to the eyes a spectacle that plain sight is powerless to access. ${ }^{68}$

Helping the people to gain access to invisible knowledge indeed was Lecouturier's goal. In his youth, he had been inspired by Azaïs' philosophy of association, not unlike Charles Fourier's fanciful cosmic theories of old. On the basis of cosmological systems, he had wished, with his "cosmosophy," to establish the "Socialism of the Universe" on the basis of principles, logic, and reason (Lecouturier 1850, 2-3, and 6). Published under the authoritarian regime of the Napoleon III, Lecouturier's Panorama of the Worlds (1858) was forcedly more moderate in tone. But by anchoring the popularization of science in the observation of the sky, starting by a long description of the telescope, Lecouturier was displacing the popular vision of the solar system more radically than ever before.

67 "l'astronomie paraît bien intéressante et bien sublime à ceux qui, au lieu de l'étudier dans les formules algébriques des mathématiciens, ne l'ont étudiée que dans le grand livre du ciel, ouvert à tous" (Lecouturier 1858, vi)

68 "la population parisienne affectionne les observations astronomiques; ce qui le démontre, ce sont les nombreuses lunettes que l'on voit établies au milieu des places publiques, sur les ponts, les quais et dans tous les lieux où se découvre une certain ampleur d'horizon. Toutes, pendant les belles soirées sereines, sont assiégées d'une foule avide de contempler les merveilles du ciel. Quelques-une sont d'un calibre trèsmodeste ; il en est qui ne supportent pas de forts grossissements, et qui ne donnent que des images d'une netteté imparfaite; mais toutes révèlent aux yeux quelque spectacle que la vue serait impuissante à découvrir" (Lecouturier 1858, 12). On Lecouturier's lunar map, see Cosmos 3 (1866), 609, as well as Lecouturier and A. Chapuis, Carte générale de la Lune, augmented by Joseph Vinot; available online: http://gallica.bnf.fr/ark:/12148/btv1b53062022g; and Lecouturier and Chapuis (No date). 
Not as much a panorama, despite its title, as an actual voyage through the solar system, his work included striking engravings reproducing the telescopic appearance of planets, comets, and nebulae. Mangin, who was Lecouturier's disciple, went even further: "explanations and descriptions, no matter how clear they are, the best made foldouts and drawings, can only give a very imperfect idea of what is occurring in the sky."69

True knowledge of the sky was only achievable through direct observation. Indirect observation was now insufficient to gain a true understanding of the universe; the only proper basis for knowledge was, perhaps not an expert practice in observational astronomy, but at least to have had some direct experiences of those observation practices. The sky had become a spectacle one needed to observe directly in order to grasp it proper meaning. And now the old dream was in sight-the spectacle of the sky was accessible truly to everyone. In an account of Billault's activities at the place Vendôme, someone pointed out that the astronomer was nice enough to accommodate the least fortunate. When instead of a fancy foreigner or a fashionable bourgeois, a brave worker asked to peek through his telescope Billault charged halfprice. "Nothing make you more democratic than the observation of the sky."70

The drive towards democratic epistemology was challenged by the Communist Revolution of 1871. When the insurgents prepared to defend Paris against the attack of the Republican troops, they occupied the place Vendôme, which was defended by a huge barricade. Later iconography took pleasure in picturing the telescope used by a cantineer to hold provisions (sausages, hams, and wine bottles) for the insurgent troops (Bell 1872, 64 and 67). Although the Communards are well known for their interest in science, the episode is often unreflectively taken up in story of the Commune, as a manifestation of a popular lack of respect for science. In another famous instance supposed to have taken place on May 16, 1871, the day the column was taken down by the insurgents, someone (or perhaps the astronomer Billault himself) rolled the

\footnotetext{
69 “les explications et les descriptions, si claires qu'elles soient, les planche et les dessins les mieux faits, ne peuvent donner qu'une idée très-imparfaite de ce qui se passe dans le ciel" (Mangin 1862, 394).

70 "quand, à la place de l'étranger, de l'élégant, du bourgeois bien mis, c'est un brave travailleur qui se présente pour regarder par les trous de la serrure du Paradis, il n'accepte que 25 centimes [instead of 50]. Rien ne rend démocrate comme la contemplation des cieux." Le Petit Journal (February 19, 1869), 1.
} 
telescope away before he got crushed. ${ }^{71}$ Whether or not the stories are true, their significance seems clear: Communist revolution was a threat to the democratic epistemology that had emerged under the Second Empire.

\section{Bibliography}

Anonymous. 1865. "L'association scientifique française." Revue nationale et étrangère, politique, scientifique et littéraire 20: 160-165.

Baedecker, Karl. 1860 Paris: Guide pratique du voyageur, 3rd edition. Paris: A. Bohné.

Belhoste, Bruno. 2011. Paris savant: parcours et rencontres au temps des Lumières. Paris: Armand Colin.

Bell, Georges. 1872. Paris Incendié. Histoire de la commune de 1871. Paris: E. Martinet.

Blancheton, Ernest. 1843. “Chevallier." Revue générale biographique, politique et littéraire 5: 207-219.

Blumenberg, Hans. 2015. The Laughter of the Thracian Woman: A Protohistory of Theory. New York: Bloomsbury Academic.

Bonnardot, Alfred. 1855. Des télescopes, causeries familères sur les télescopes de tous genres, leurs effets, leur théorie, l'époque de leur invention, leurs perfection- nements successifs et leur avenir. Traité spécialement écrit pour les gens du monde, suivi d'une dissertation sur les astronomes amateurs. Paris: Mallet-Bachelier.

Brenni, Paolo. 1996. "19th Century French Scientific Instrument Makers XIII: Soleil, Duboscq, and Their Successors." Bulletin of the Scientific Instrument Society (51): 7-16.

Béguet, Bruno. 1990. “Le livre de vulgarization scientifique.” In La Science pour tous: Sur la vulgarisation scientifique en France de 1850 à 1914, edited by Bruno Béguet. Paris: Bibliothèque du CNAM.

Caraguel, Clément. 1850. “Un mystère dans la Lune.” L'Argus des théâtres 2 (October 30): n.p.

Champagnac, Jean-Baptiste-Joseph. 1841. Travail et industrie, le pouvoir de la volonté: histoires d'artisans, d'artistes et de négociants devenus célèbres. Paris: Lehuby.

${ }^{71}$ Le Radical (14 juillet 1891). On science during the Paris Commune, see Michèle Audin's blog: https://macommunedeparis.com. 
Charrin, Pierre-Joseph. 1815. Dictionnaire des girouettes, ou nos contemporains peints d'après eux-mêmes, 2nd ed. Paris: Alexis Eymery.

Chevalier, Jean-Gabriel-Auguste. 1815. Le Conservateur de la vue. Paris: published by the author.

Chevalier, Jean-Gabriel-Auguste. 1819. Essai sur l'art de l'ingénieur en instrumens de physique expérimentale en verre. Paris: published by the author and by Madame Huzard, Delaunay, \& Pillet.

Claretie, Jules. 1867. "Les places publiques, les quais et les squares de paris." In Paris guide par les principaux écrivains et artistes de la France, 1381-1411. Paris: Librairie international.

Cogniard, Théodore, and Clairville [Louis-François Nicolaïe]. 1858. As-tu vu la comète, mon gas [sic]: Revue de l'année 1858, en trois actes et quatorze tableaux. Paris: Michel Levy.

Considerant, Victor, Raymond Brucker, and Francis Wey. 1836. Publication complète des nouvelles découverte de Sir John Herschel dans le ciel austral et dans la Lune. Paris: Masson et Duprey.

Cooter, Roger, and Stephen Pumfrey. 1994. "Separate Spheres and Public Places: Reflections on the History of Science Popularization and Science in Popular Culture." History of Science 32: 237-267.

Crary, Jonathan. 1990. Techniques of the Observer: On Vision and Modernity in the Nineteenth Century. Cambridge, Mass.: MIT Press.

Dabot, Henri. 1903-1905. Calendriers d'un bourgeois du Quartier Latin. Péronne: E. Quentin.

Daum, Andreas. 2002. Wissenschaftspopularisierung im 19. Jahrhundert, Bürglische Kultur, naturwissenschaftliche Bildung und die deutsche Öffentlichkeit 1848- 1914. Munich: R. Oldenburg.

Dinaux, Arthur. 1829. "Le chevalier Hennet." Archives historiques et littéraires du Nord de la France et du Midi de la Belgique 1: 477-485.

Donné, Alfred. 1836a. “Découvertes dans la lune, faites au cap de Bonne-Espérance par Herschel fils (traduit de l'Américain de New-York)." Journal des débats (March 9): n. p. 
Dumonteil, Fulbert. 1867. "L'astronome du Pont-Neuf." La Rue: journal pittoresque et populaire (June 22): 4-6.

Établissements de Pixii. 1824. Catalogue d'instrumens de physique, chimie, optique, mathématiques et autres à l'usage des sciences. Paris: Huzard-Courcier.

Fages, Volny. 2012. "Les Origines du monde. Cosmogonies scientifiques en France (1860-1920)." PhD thesis, EHESS, Paris.

Flammarion, Berthe. 1887. Histoire très vraie de trois enfants courageux. Paris: C. Marpon and E. Flammation.

Flammarion, Camille. 1880. L'Astronomie Populaire. Paris: Gauthier-Villars.

Flammarion, Camille. 1912. Mémoires biographiques et philosophiques d'un astronome. Paris: E. Flammarion.

Flammarion, Camille. 1918. "La Société Astronomique de France dans sa cinquième année de guerre." L'Astronomie 32: 381-397.

Flaubert, Gustave. 1881. Bouvard et Pécuchet: œuvre posthume. Paris: A. Lemerre. Fonvielle, Wilfrid de. 1889. "Les astronomes de la place publique, à Paris." La Nature 17 (1): 236-238.

Fowler, Harold N. ed. 1921. Platon in Twelve Volumes. London: William Heinemann.

Fuentes, Patrick. 1998. "Les astronomes en plein vent." L'Astronomie 112: 92-96.

Gasperini, Antonella, Daniele Galli, and Lara Nenzi. 2011. "The worldwide impact of Donati's comet on art and society in the mid-19th century." In The Rôle of Astronomy in Society and Culture: Proceedings of IAU Symposium no. 260, edited by D. VallsGabaud and A. Boksenberg, 340-345. Cambridge: Cambridge University Press.

Gille, Charles, ed. 1844. La Chanson de nos jours: chansons populaires contemporaines. Paris: Eyssautier.

Hannossh, Michele. 1992. Baudelaire and Caricature: From the Comic to an Art of Modernity. University Park, Penn.: The Pennsylvania State University Press.

Heine, Heinrich. 1833-1835. OEuvres de Henri Heine. Paris: Eugène Renduel.

Heine, Heinrich. 1866. Lutèce: lettres sur la vie politique, artistique et sociale de la France, 2nd ed. Paris: Michel Lévy Frères. 
Hennet, Albert-Joseph-Ulpien. 1820. Le Globe celeste, cours d'astronomie contemplative. Paris: Delamarche \& Dien, and Veuve Courcier.

Herzen, Aleksandr. 1870. De l'autre rive, 5th ed. Geneva: published by the author.

Houziaux, Léo. 2012. "Inspired by the skies: Saint-saëns, amateur astronomer.” In Camille Saint-Saëns and his world, edited by Jann Pasler, 12-17. Princeton: Princeton University Press.

Hugues, A. 1868. L'Observatoire et ses merveilles: deux journée instructives et amusantes. Paris: Grassart, , 1868.

Jouy, Étienne de. 1813. L'Hermite de la Chaussée d'Antin: ou, observations sur les mœurs et les usages française au commencement du XIXe siècle. Paris: Pilet.

Kastner, Georges. 1857. Les Voix de Paris: essai d'une histoire littéraire et musciale des cris populaires de la capitale depuis le Moyen Âge jusqu'à nos jours, précédé de considérations sur l'origine et le caractère du cri en général et suivi de Les cris de Paris, grande symphonie humoristique vocale et instrumentale. Paris: G. Brandus, Jules Renouard.

King, Henry C. 1955. The History of the Telescope. Mineola, N.Y.: Dover.

La Tour de Lajonchère, Auguste Gay de, and Clairville [Louis-François Nicolaïe]. 1837. 1836 dans la Lune: revue mêlée de couplets, précédée de "L’Astronome du Quai des Lunettes". Paris: Morain.

Lecouturier, Henri. 1850. Cosmosophie, ou le socialisme universel. Paris: published by the author.

Lecouturier, Henri. 1858 Panorama des mondes: Astronomie planétaire. Paris: Musée des sciences.

Lecouturier, Henri, and A. Chapuis. No date. La Lune, description et topographie: pour servir à l'explication de la carte de la Lune des mêmes auteurs. Paris: no publisher.

Leuven, Adolphe de, and Léon-Lévy Brunswick. 1849. La Foire aux idées: journalvaudeville en 3 actes, no. 3. Paris: Michel Lévy frères.

Mangin, Arthur. 1862. Voyage scientifique autour de ma chambre. Paris: Musée des familles. 
Martin, Alexis. 1890. Les Étapes d'un touriste en France: Paris, promenades dans les 20 arrondissements. Paris: A. Hennuyer.

Martin, C. A. 1860. “Chronique scientifique.” Le Monde illustré 4(169): 7 and 10.

McCabe, James D. 1869. Paris by Sunlight and Gaslight: A Work Descriptive of the Mysteries and Miseries, the Virtues, the Vices, the Splendors, and the Crimes of the City of Paris. Philadelphia: National Publishing Company.

Moigno, François. 1863. “Astronomie en plein vent.” Cosmos 2: 252-253.

Moineaux, Jules, and Émile Durand. No date. L'Astronome du Pont-Neuf, pochade musicale en un acte. Paris: 0. Borneman.

Navery, Raoul de. 1864. “Association scientifique: séance de rentrée à l'observatoire impérial." Nouvelle Revue de Paris 6:559-564.

Nieto-Galan, Augustí. 2016. Science in the Public Sphere: A History of Lay Knowledge and Expertise. London: Routledge.

Ourry, Maurice, and Jean-Baptiste Sauvans. 1818. Petite chronique de Paris: historique, littéraire et politique, faisant suite aux Mémoires de Bachaumont. Paris: Veuve Perronneau, Delaunay, and Eymery, Mongie.

Parinet, Élisabeth. 1992. La Librairie Flammarion, 1875-1914. Paris: IMEC, Paris.

Phelan, Anthony. 2006. Reading Heinrich Heine. Cambridge: Cambridge University Press.

Piet, F. 1836. Mémoires sur la vie et les ouvrages d'Éd. Richer. Nantes: Mellinet.

Pujoulx, Jean-Baptiste. 1801. Paris à la fin du XVIIIe siècle, ou Esquisse historique et morale des monumens et des ruines de cette capitale, de l'état des sciences, des arts et de l'industrie à cette époque, ainsi que des mours et des ridicules de ses habitans. Paris: Brigite Mathé.

Quatrefages, Armand de. 1854. Souvenirs d'un naturaliste. Paris: Charpentier.

Raspail, François-Vincent. 1858-1859. “De la comète.” Revue complémentaire des sciences appliquées à la médecine et pharmacie, à l'agriculture, aux arts et à l'industrie 5: 120123

Saint-Firmin [Alexandre Ferré]. 1836. Maître Job ou ma femme et mon telescope: vaudeville en un acte. Paris: no publisher. 
Saint-Saëns, Camille. 1911. “L'observation astronomique.” L'Astronomie 25: 417-422.

Secord, Ann. 1994. "Science in the Pub: Artisan Botanists in Early Nineteenth-Century Lancashire." History of Science 32:269-315.

Secord, James A. 2000. Victorian Sensation: The Extraordinary Publication, Reception, and Secret Authorship of "Vestiges of the Natural History of Creation". Chicago: Chicago University Press.

Texier, Edmond. 1852. Tableaux de Paris. Paris: Paulin et Le Chevalier.

Texier, Edmond. 1867. “Les petites industries.” In Paris-Guide par les principaux écrivains et artistes de la France 2: 963-971. Paris: Librairie internationale and A. Lacroix, Verboeckhoven et Cie.

Thébaud-Sorger, Marie. 2015. Spectacles de sciences. Histoire des Sciences et Savoirs, edited by Dominique Pestre, 2: 133-153. Paris: Le Seuil.

Topham, Jonathan R. 2009. "Rethinking the History of Science: Popularization/Popular Science." In Popularizing Science and Technology in the European Periphery, 18002000, edited by Faidra Papanelopoulou, Agustí Nieto-Galan, and Enrique Perdiguero, 1-20. Farnham: Ashgate.

Vogl, Joseph. 2008. “Becoming-Media: Galileo’s Telescope.” Grey Room 29:14-25

Wise, M. Norton. 1988. “Mediating Machines.” Science in Context 2:77-113. 